\section{The Wear Performance of Glazed and Polished Full Contour Zirconia}

Larissa Marcia Martins Alves ${ }^{1}\left[{ }^{0}\right.$, Lisseth Patricia Claudio Contreras ${ }^{1}{ }^{\mathbb{D}}$, Mirian

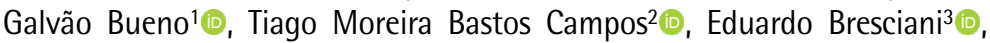
Marcia Carneiro Valera ${ }^{3}$, Renata Marques de Melo ${ }^{1}$ (D)
'Department of Dental Materials and Prosthodontics, UNESP Universidade Estadual Paulista, São José dos Campos, SP, Brazil ${ }^{2}$ Department of Physics, ITA Instituto Tecnológico de Aeronáutica, São José dos Campos, SP, Brazil ${ }^{3}$ Department of Restorative Dentistry, UNESP - Universidade Estadual Paulista, São José dos Campos, SP, Brazil

Correspondence: Larissa Marcia Martins Alves, Avenida Eng. Francisco José Longo, 777, 12245-000 São José dos Campos, SP, Brasil. Tel: +55-12-9 8174-5195.e-mail: larissammalves@gmail.com

Key Words: dental materials, ceramics, zirconium, dental restoration wear.

\section{Introduction}

Wear in the dental structure is a natural process that occurs by contact and friction between opposing teeth, which can be accelerated when a natural tooth is in contact with restorative materials (1). At the beginning, the wear of teeth in contact with ceramics was associated with the hardness of the material (2), but it is known that this relationship is not direct, and that higher wear is related to the roughness of the restoration (3).

Zirconia is a polycrystalline material that can appear in monoclinic, tetragonal and cubic forms. The excellent properties of this material are due to the transformation of the tetragonal phase into the monolithic phase, which can be induced by thermomechanical factors, resulting in a volume increase of 3 to $4 \%$ and generates compressive surface stress, making it a material of high resistance to fracture (4). Specifically, the roughness on full contour zirconia surfaces can vary due to CAD-CAM milling (5), clinical adjustments (6), the type of surface finishing (7) and low temperature degradation (8). Although zirconia is a material with greater hardness compared to other ceramics, a study has shown that it can produce less wear on the dental structure of antagonistic teeth when compared to feldspathic ceramics (9). According to Passos et al. (10), the more the zirconia is polished, the lower the wear on the antagonist tooth. In testing different polishing techniques on the zirconia surface, Chong et al. (11) stated that it may wear off the enamel because of its hardness and coefficient of friction, and it is extremely important to polish the restoration after adjustments to minimize wear. Glazing is another option for finishing the monolithic zirconia surface, although works show that it can be deleterious to the antagonist enamel $(12,13)$.

It is evident in the literature that zirconia can generate certain wear on the enamel of antagonistic teeth as well as to other materials, and that polishing can reduce these effects, but it is not yet known how the combined effects of material type and surface finishing can act on the antagonist. Therefore, the purpose of the present study was to evaluate the influence of full contour zirconia glazing, polishing and glazing after polishing on the wear of and enamel analogue material. The null hypothesis was that there would be no difference in the wear induced by different surface finishes of a zirconia to the enamel analogue.

\section{Material and Methods}

\section{Preparation of Specimens}

Forty discs were prepared from four CAD/CAM (Computer Aided Design/Computer Aided Manufacture) blocks (39 x 19 × 15.5 mm; VITA In-Ceram YZ; Vita 
Zahnfabrik H.RauterGmbH\&Co., BadSäckingen, Germany). A ring device was then glued onto the top surfaces of the blocks to round them until $14 \mathrm{~mm}$ diameter cylinders were obtained (Fig. 1).

The cylinders were finally cut into several smaller discs in a cutting machine (Isomet 1000, Buehler, Lake Bluff, IL, USA). The first section (approximately $0.5 \mathrm{~mm}$ ) was discarded, and the remaining sections (1.65 $\mathrm{mm}$ thickness) were cut under coolant irrigation. The discs were sintered following the manufacturer's instructions (Vita Zahnfabrik H.RauterGmbH\&Co., BadSäckingen, Germany) according to the following schedule: temperature elevation time, $1 \mathrm{~h}$; final temperature, $1530{ }^{\circ} \mathrm{C}$; waiting time, $2 \mathrm{~h}$; and cooling temperature at which the tray can be downloaded inside the oven, $400{ }^{\circ} \mathrm{C}$. The final diameter and thickness were $12 \mathrm{~mm}$ and $1.2 \mathrm{~mm}$, respectively.

The specimens were polished with $\mathrm{SiC}$ abrasive paper \#1200, and divided into four groups: polished, glazed,

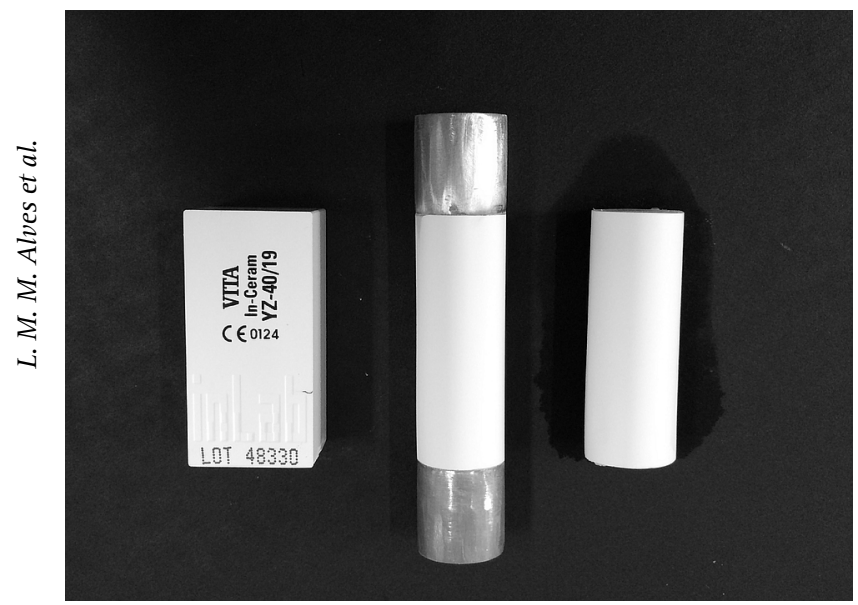

Figure 1. Zirconia cylinder: a block (A) was glued to a round index (B) and rounded until reaching the desired format and dimensions (C). polished+glazed and without finish. Each group $(n=10)$ was then subjected to wear with steatite in order to simulate the wear.

For the polished group, polishing was performed manually by one operator with the progressive use of points of decreasing granulation (EVE DIACERA Ceramics Kit, EVE, Pforzheim, Baden-Württemberg, Germany) using a thick one (green) followed by a medium one (pink) at a speed of 7,000 to $12,000 \mathrm{rpm}$ per $15 \mathrm{~s}$, both mounted on a laboratory motor handpiece (MF Perfecta 9975, W\&H, Laufen, Germany). For glazed groups, VITA AKZENT Plus BODY STAINS (Vita Zahnfabrik H.RauterGmbH\&Co) was applied on a $12 \mathrm{~mm}$ diameter surface and fired in a vacuum furnace (Vita Vacumat 6000, Vita Zahnfabrik H.RauterGmbH\&Co), following the protocol recommended by the manufacturer (initial temperature, $500^{\circ} \mathrm{C}$; pre-drying time, $4 \mathrm{~min}$; heating time, $5.37 \mathrm{~min}$; temperature elevation rate, $80{ }^{\circ} \mathrm{C} / \mathrm{min}$; final temperature, $950{ }^{\circ} \mathrm{C}$; and dwelling time at the final temperature, $1 \mathrm{~min}$ ).

\section{Wear Testing}

For the wear test, $2 \mathrm{~mm}$ steatite pistons (magnesium silicate, Ceramica Chiarotti, Jaguariúna, São Paulo, Brazil) mounted on a two-body machine to generate sliding wear were used as the antagonists (Biocycle V2, Biopdi, São Carlos, São Paulo, Brazil), as seen in Fig. 2. The wear machine operates by applying a vertical load on the specimen, sliding horizontally, and then repeating the cycle. The parameters for this test were as follows: load of $25 \mathrm{~N}$, frequency of 1.7 $\mathrm{Hz}$, sliding distance of $4 \mathrm{~mm}$ and 300,000 cycles in distilled water. Water was used as lubricant and worn particles were constantly renewed.

\section{Assessment of Wear}

Quantitative wear measurements were performed on

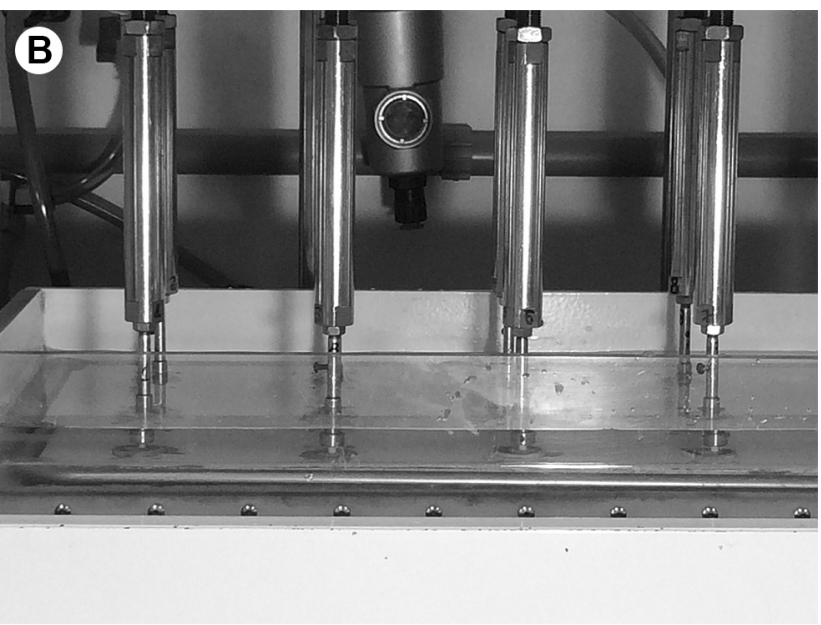

Figure 2. Wear machine (A) and pistons in position with the samples (B). 
both antagonists and discs. In order to obtain volumetric wear of steatite, the diameter was measured after testing with an optical microscope. The volumetric loss was calculated by Sajewicz's (14) calculations. In addition, the mass of worn steatites was determined using an analytical balance before and after the wear (Adventurer ${ }^{\circledR}$ - AR Analytical, Ohaus, Barueri, São Paulo, Brazil) with a resolution of $0.1 \mathrm{mg}( \pm 0.1 \mathrm{mg})$.

The wear of the discs was determined in a digital optical profilometer (CyberSCAN CT 100, CyberTECHNOLOGIES $\mathrm{GmbH}$, Eching-Dietersheim, Germany). The profilometer was connected to the computer through CyberTECHNOLOGIES SCAN 8.6.5546 software. The software generated a 3D image of the surface profile and quantified the wear.

\section{Surface Analyses}

To determine the effect of the finishes on the topography and roughness (Ra) of the monolithic zirconia, the specimens were first analyzed in a contact rough meter ( $n=10$, Mitutoyo SJ-410, Mitutoyo Corporation, Takatsuku, Kawasaki, Kanagawa, Japan) with 6 measurements performed on each specimen (Ra - arithmetic mean of absolute values of peaks and valleys measured from a median plane with a $0.8-\mathrm{mm}$ cut-off and sampling evaluation length of $2.4 \mathrm{~mm}$ ). The mean Ra for each specimen was then obtained. A representative sample of each group was also evaluated in digital optical profilometer (Wyko NT model 1100, Veeco, Tucson, USA). The information obtained from the profilometer was transferred to the computer through Wyko software version 32 (Veeco, Tucson, USA) to generate three dimensional images.

\section{Scanning Electron Microscopy (SEM)}

The ceramic surfaces of all groups were further analyzed using a scanning electron microscope (SEM; JSM-6360,
JEOL, Tokyo, Japan). One specimen of glazed group was perpendicularly cut in two parts and analyzed by a field emission gun (FEG-SEM; Mira 3, Tescan, Brno, Czech Republic). To perform the measurements, the specimens were coated with a gold-palladium alloy spray and inspected to evaluate the surface pattern.

\section{Wettability Test}

Five (5) samples from each group were used for the wettability test. A tensiometer (TL 1000, One Attension, Lichfield, Staffordshire, UK) was used to measure the mean contact angle in five distinct areas of each sample by the sessile drop technique with deionized distilled water at room temperature. A graduated syringe (Gastight Syringes \# 1001-1ml, Hamilton, Reno, Nevada, USA) with a hydrophobic needle deposited a drop, then the mean contact angle was calculated after waiting $5 \mathrm{~s}$ (One Attension, BiolinScientific, Lichfield) from 60 images acquired per second for $30 \mathrm{~s}$.

\section{Statistical Analysis}

Descriptive statistics, including means, medians, standard deviation, maximum and minimum were calculated with GraphPad Prism 5.0 statistical software package (GraphPad Software, Inc., San Diego, CA). Statistical differences in the means of wettability were analyzed by one-way ANOVA with the post-hoc Tukey test $(\alpha=0.05)$, whereas for nonparametric data of roughness, volumetric wear and mass loss the Kruskal-Wallis test, followed by the Dunn test, was applied $(p<0.05)$.

\section{Results}

\section{Roughness}

Table 1 presents the descriptive statistical analysis for roughness data (Ra). Kruskal-Wallis showed significant differences between finishes ( $p$-value $=0.0001) \quad($ Table 1$)$. The lowest values of Ra were found in the polished group, similar to the roughness of samples without finishing (control), whereas polished and glazed group showed the highest values.

\section{Wear Testing}

Median values and standard deviations of both steatite and discs volumetric wear and mass loss are listed in Table 1. Kruskal-Wallis showed significant differences 
between finishes for steatite wear ( $p$-value $=0.0001$ ), discs wear ( $p$-value $=0.0002)$ and steatite mass loss $(p-$ value $=0.000)$ (Table 1$)$. Figure 3 shows the vertical wear promoted on discs.

The specimens from the glazed groups significantly reduced wear on the antagonists. Following the glazed group, the polished one was the least abrasive. On the other hand, the discs volumetric wear was significantly higher on glazed groups, whereas polished and sintered groups showed less wear.

\section{Scanning Electron Microscopy (SEM)}

SEM micrographs displayed in Figure 4 showed different surface patterns: the control group showed an irregular surface (Fig. 4B), the polished group presented a surface with grooves (Fig. 4D) and the glazed group had a homogeneous surface (Fig. 4F). However, in the group in which the finishes were associated, the surface presented the formation of some pores and defects (Fig. 4H). In addition, it was possible to observe the removal of surface finishes caused by wear as well as the grooves of the control group (arrows), and that all groups presented similar surfaces after wear. The FEG-SEM micrograph of glazed group (Fig. 5) showed the interface between worn and non-worn areas. It is possible to observe that the glaze layer was removed after the wear and, but still a thin layer was present (arrows).

\section{Profilometry}

Figure 6 shows the images obtained in 3D digital optical profilometer for each of the groups. The control (Fig. 6A) and polished groups (Fig. 6B) presented surfaces with irregularities in comparison to the other groups. The glaze group had a more regular and homogeneous surface, but there was pore formation when associated with polishing (Fig. 6G).

\section{Wettability}

One-way ANOVA showed that surface finishes were statistically different ( $p$-value $=0.021$ ) (Table 1). Surfaces of the control, polished and glazed groups showed similar contact angle values. However, specimens in the polished and glazed groups showed the lowest mean contact angle, with only the polished group being statistically different. All groups had values lower than 90 degrees, characterizing the surfaces as hydrophilic.

\section{Discussion}

According to the results, the null hypothesis was rejected under the tested conditions, since glazed surface finish caused less wear on the antagonist, whereas the polished group or no finish caused more wear.

The attrition between the dental enamel analogue and the zirconia was simulated in a sliding mechanical cycling machine, with the zirconia submitted to different surface finishes (no finish, glaze, polishing and association of polishing and glaze). The amount of steatite wear was evaluated by two methods, in the first was measurement of the weight difference of the steatite before and after the test. This method of quantifying wear is present in the
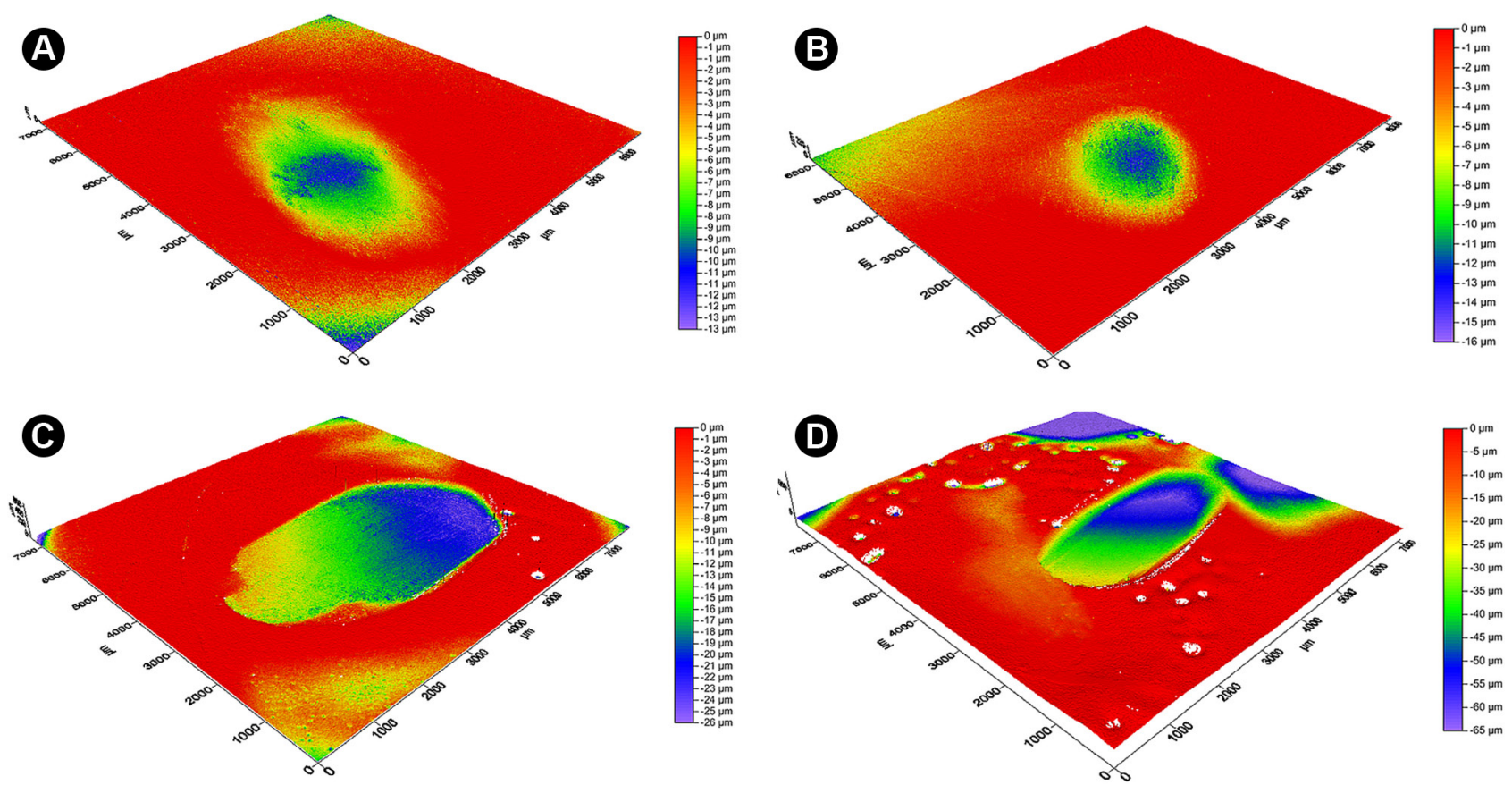

Figure 3. Profilometry (3D) images showing different topographic patterns after wear. A) Control; B) Polished; C) Glaze; D) Polished and glazed. It is possible to verify the accentuated wear of glazed groups compared to the others. 

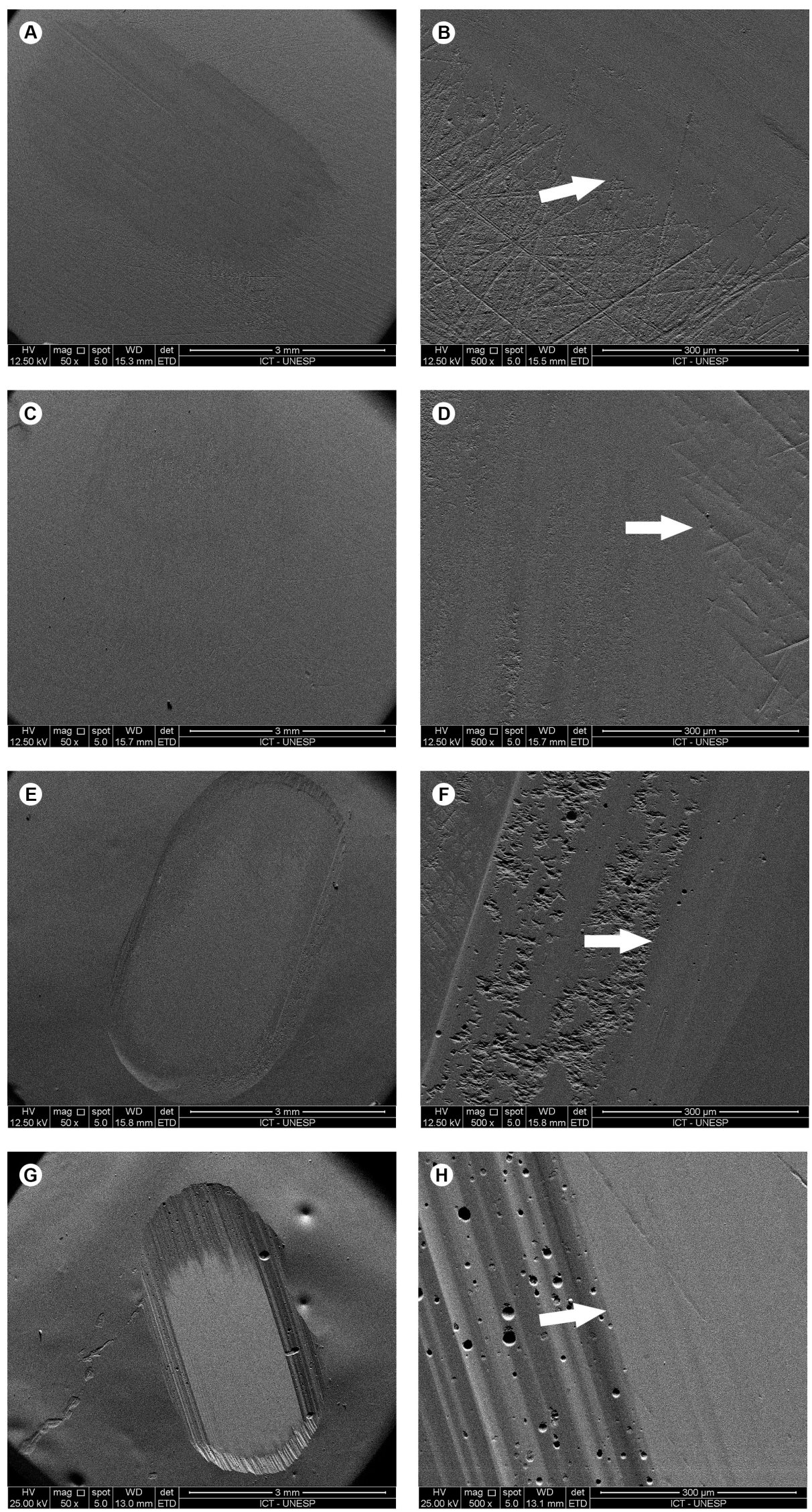

Figure 4. SEM micrographs (magnification of 50x: A, C, E, G and 500x: B, D, F, H) showing different patterns of microstructure of the specimens and the wear promoted according to the finish. A, B) Control; C, D) Polished; E, F) Glaze; G, H) Polished and glazed. At lower magnification it is possible to observe the removal of surface finishes; at higher magnification one can see the boundary between the worn and the non-worn areas (arrows). 
literature (15), but it is complemented by other methods of quantification. Profilometry images is the other way to calculate the wear (16). Our study complemented the quantification based on the methodology described by Sajewicz's (14), in which the diameter of antagonist is measured, before and after the test, and these values are used in a formula that results in the amount of volume loss.

Non finished zirconia presented similar or even lower roughness than the other groups and in the SEM showed a surface with more surface scratches (Fig. 4), which may be a consequence of using \#1200 sandpaper to flatten specimens before sintering. In spite of the lower roughness of this group showed, greater wear of steatite when compared to glazed groups was noticed, which is in agreement with Singh et al. (17) in which the groups with higher surface roughness were not responsible for the greater wear of the antagonist. Therefore, other factors such as physical ones - hardness, frictional resistance, fracture toughness- and/or microstructural ones - porosities, crystals - might be involved in the wear of the antagonist (18).

The polished group presented grooves from the polishing process observable in SEM (Fig. 4), but it had the same roughness as control group. On the other hand, its roughness was lower than that of glazed groups and caused more wear on the antagonist. This suggests that with the polishing system used herein, it is unlikely that the surface topography of zirconia can be altered by polishing alone.

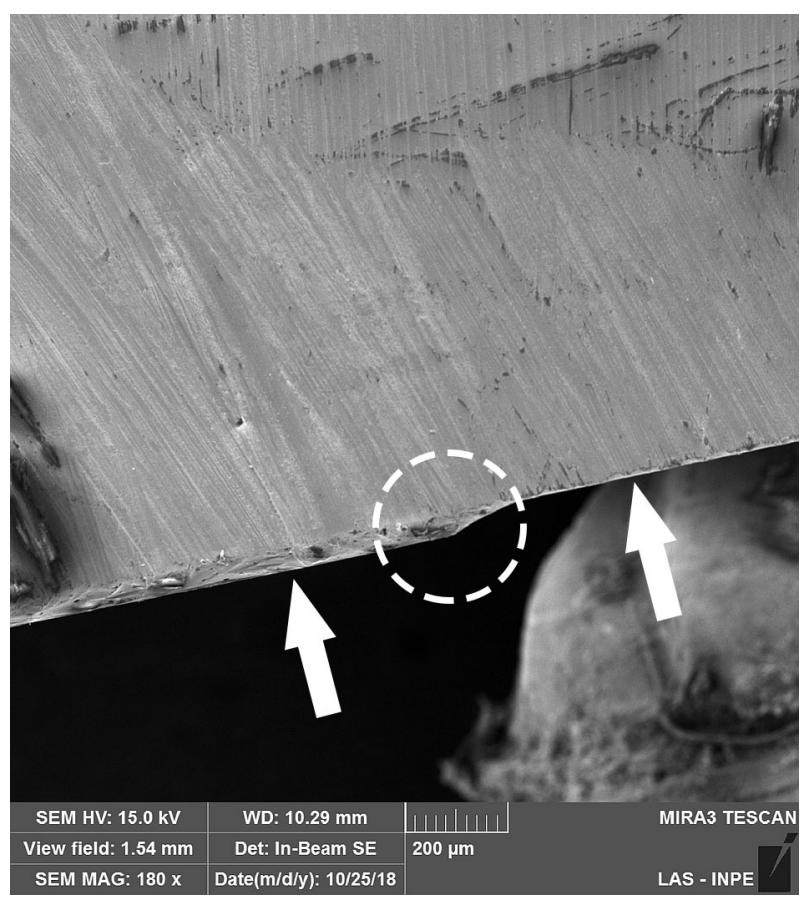

Figure 5. FEG-SEM micrograph (180x magnification) showing the interface between worn and non-worn areas of glazed specimen. It is possible to observe that the glaze layer was removed after the wear, but still a thin layer is present (arrows).
Our results resemble those found by Mitov et al. (7), which compared the surface roughness of polished and glazed zirconia as well as the amount of wear of the antagonist enamel after such surface finishes and no significant linear correlation was found between surface roughness and antagonist abrasive wear.

In this perspective, studies have reported a greatest wear potential of glazed zirconia compared to polished zirconia $(19,20)$, differently from the results of this research since the glazed groups provided less wear to the antagonist. This variation could be due to different finishing methods (21).

The wear process in ceramic materials occurs from the formation of cracks, posterior crack propagation and fracture; according to DeLong et al. (22), this type of wear is called abrasive wear. Therefore, the ability of the ceramic material to resist fracture is an important factor in the wear process as the particles around the wear scar can become sharp after chipping, thus increasing the wear (18).

In this regard, the lowest wear values of the glazed groups were probably due to the thin homogeneous layer being quickly abraded, and no debris due to fracture causing the abrasiveness to the antagonist (23). In addition, the volumetric wear was higher in the glazed groups, probably because this volumetric loss involves the glaze layer and not only the zirconia structure (Fig. 5), as in the polished and control groups (16)

Regarding the wettability analysis, the polished and glazed group had lower values of contact angle than polished group (Table 1), hydrophilic surfaces decrease wear by promoting a low coefficient of friction and improved lubrication. Consequently, as the zirconia roughness increased, the contact angle decreased, and the surface became more wettable, which may have resulted in higher lubrication in the wear process, minimizing the formation of debris and generating less abrasion.

Steatite is a material used in laboratory tests as analogous to dental enamel because they allowed the standardization of antagonistic conditions (13). This enamel substitute caused more evident wear scars on the surface of glazed groups than on control and polished groups alone. However, shallower wear marks were seen on the zirconia of the latter groups, contrary to the findings of Kwon et al. (24), in which no wear scars were seen after wearing zirconia against enamel cusps. The authors blamed the high toughness of these materials on the absence of significant scars, but our results showed a clear difference between the worn and non-worn neighboring surfaces. This is important because the use of highly translucent low tough full contour zirconia at small thickness has increased.

Furthermore, dental wear is a multifactorial condition that can occur due to chemical and or mechanical factors. Loss of tooth structure which is not caused by caries can 

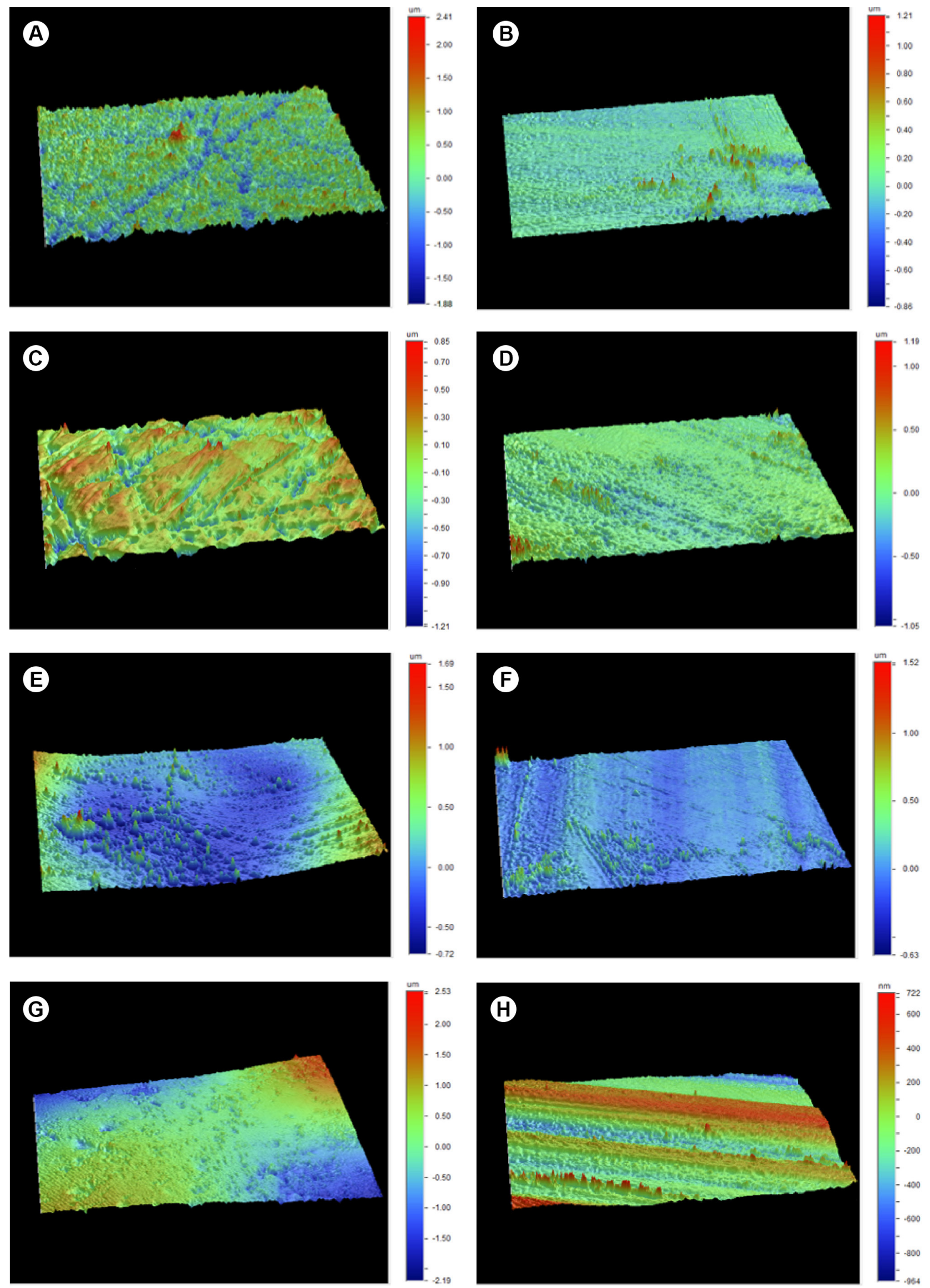

Figure 6. 3D optical profilometry images representing the surface topography of the groups, showing different topographic patterns of the specimens before (left) and after (right) wear. A, B) control; C, D) polished; E, F) glazed; G, H) polished and glazed. 
also be qualified as abrasion, erosion, attrition or abfraction, with attrition being produced by contact between teeth, or between teeth and restorative materials during mastication or parafunctional habits (25). The amount of dental structure lost by the effects of attrition against restorative materials is only one of many issues related to wear such as chewing frequency, dietary abrasiveness, surface roughness, or intraoral oral composition, and which should be considered in future studies (26).

Within the limitations of this in vitro study, it is possible to conclude that glazed zirconia caused less wear on the antagonist when compared to no finish and polished zirconia. In addition, no significant difference was found on the amount of antagonist wear for polished and control groups.

\section{Resumo}

Este estudo avaliou a influência dos acabamentos superficiais da zircônia no desgaste de um análogo de esmalte. 40 discos de zircônia foram divididos em quatro grupos: controle (sem acabamento); glazeado; polido; polido e glazeado. Todas as amostras foram submetidas ao desgaste contra antagonistas de esteatita. Os espécimes foram submetidos à análise de rugosidade, topografia, microscopia eletrônica de varredura (MEV) e análise de molhabilidade. Medidas quantitativas de desgaste foram realizadas nos antagonistas e nos discos de zircônia. Para medir o $\tau$ desgaste das esteatitas, foi mensurado o peso antes e depois do desgaste e o diâmetro após o teste. A análise de perfilometria mensurou o desgaste dos discos. Rugosidade, desgaste volumétrico e perda de massa foram analisados pelos testes de Kruskal-Wallis e Dunn (5\%), enquanto os valores de ângulo de contato foram analisados com os testes One-way ANOVA e Tukey (5\%). 0 grupo polido apresentou as menores médias de rugosidade, sendo estatisticamente diferente dos demais grupos ( $p$-valor $=0,0001)$. 0 grupo glazeado apresentou o menor desgaste volumétrico do antagonista ( $p$-valor $=0,0001)$, mas não foi estatisticamente diferente do grupo polido e glazeado, enquanto que esses grupos apresentaram o maior desgaste volumétrico da zircônia, com diferença estatisticamente diferente ( $p$-valor $=0,0002)$ em comparação com os outros. MEV mostrou irregularidades na superficie do grupo controle, sulcos no grupo polido e uma superficie homogênea para o grupo glazeado, com poucos poros. Todos os grupos apresentaram ângulos de contato menores que 90 graus, caracterizando superfícies hidrofílicas. Dentro das limitações deste estudo in vitro, é possivel concluir que zircônia glazeada causou menos desgaste ao antagonista quando comparada a zircônia sem tratamento ou polida. Além disso, não foi encontrada diferença no desgaste do antagonista para os grupos de zirconia polida e controle.

\section{References}

1. Wiley MG. Effects of porcelain on occluding surfaces of restored teeth. J Prosthet Dent 1989;61:133-137.

2. Hudson JD, Goldstein GR, Georgescu M. Enamel wear caused by three different restorative materials. J Prosthet Dent 1995;74:647-654.

3. Seghi RR, Rosenstiel SF, Bauer P. Abrasion of human enamel by different dental ceramics in vitro. J Dent Res 1991;70:221-225.

4. Chevalier J, Gremillard L, Virkar AV, Clarke DR. The tetragonalmonoclinic transformation in zirconia: lessons learned and future trends. J Am Ceram Soc 2009;92:1901-1920.

5. Alao AR, Stoll R, Song XF, Miyazaki T, Hotta $Y$, Shibata $Y$, et al. Surface quality of yttria-stabilized tetragonal zirconia polycrystal in CAD/CAM milling, sintering, polishing and sandblasting processes. J Mech Behav
Biomed Mater 2017:65:102-116.

6. Preis V, Schmalzbauer M, Bougeard D, Schneider-Feyrer S, Rosentritt M. Surface properties of monolithic zirconia after dental adjustment treatments and in vitro wear simulation. J Dent 2015;43:133-139.

7. Mitov G, Heintze SD, Walz S, Woll K, Muecklich F, Pospiech P. Wear behavior of dental Y-TZP ceramic against natural enamel after different finishing procedures. Dent Mater 2012;28:909-918.

8. Yoshimura $M$, Noma $T$, Kawabata $K$, Somiya $S$. Role of $\mathrm{H} 2 \mathrm{O}$ on the degradation process of Y-TZP. J Mater Sci Lett 1987;6:465-467.

9. Jung YS, Lee JW, Choi YJ, Ahn JS, Shin SW, Huh JB. A study on the in-vitro wear of the natural tooth structure by opposing zirconia or dental porcelain. J Adv Prosthodont 2010;2:111-115.

10. Passos SP, Torrealba $Y$, Major $P_{1}$ Linke B, Flores-Mir C, Nychka JA. In vitro wear behavior of zirconia opposing enamel: a systematic review. J Prosthodont 2014;23:593-601.

11. Chong BJ, Thangavel AK, Rolton SB, Guazzato M, Klineberg IJ. Clinical and laboratory surface finishing procedures for zirconia on opposing human enamel wear: A laboratory study. J Mech Behav Biomed Mater 2015;50:93-103.

12. Rupawala A, Musani SI, Madanshetty P, Dugal R, Shah UD, Sheth EJ. A study on the wear of enamel caused by monolithic zirconia and the subsequent phase transformation compared to two other ceramic systems. J Indian Prosthodont Soc 2017;17:8-14.

13. Preis V, Grumser K, Schneider-Feyrer S, Behr M, Rosentritt M. Cycledependent in vitro wear performance of dental ceramics after clinical surface treatments. J Mech Behav Biomed Mater 2016;53:49-58.

14. Sajewicz E. On evaluation of wear resistance of tooth enamel and dental materials. Wear 2006;260:1256-1261.

15. Zhang Z, Yi Y, Wang X, Guo J, Li D, He L, et al. A comparative study of progressive wear of four dental monolithic, veneered glass-ceramics. J Mech Behav Biomed Mater 2017;74:111-117.

16. Lawson NC, Janyavula S, Syklawer S, McLaren EA,Burgess J0. Wear of enamel Opposing zirconia and lithium disilicate after adjustment, polishing and glazing. J Dent 2014;42:1586-1591.

17. Singh $A$, Nagpal A, Pawah $S$, Pathak $C$, Issar $G$, Sharma P. Qualitative assessment of wear resistance and surface hardness of different commercially available dental porcelain: an in vitro study. J Contemp Dent Pract 2016;17:755-761.

18. Oh WS, Delong R, Anusavice KJ. Factors affecting enamel and ceramic wear: a literature review. J Prosthet Dent 2002;87:451-459.

19. Elmaria A, Goldstein G, Vijayaraghavan T, Legeros RZ, Hittelman EL. An evaluation of wear when enamel is opposed by various ceramic materials and gold. J Prosthet Dent 2006;96:345-353.

20. Heintze SD, Cavalleri A, Forjanic M, Zellweger G, Rousson V. Wear of ceramic and antagonist-a systematic evaluation of influencing factors in vitro. Dent Mater 2008;24:433-449.

21. Yilmaz K, Ozkan P. The methods for the generation of smoothness in dental ceramics. Compend Contin Educ Dent 2010;31:30-38.

22. DeLong R, Douglas WH, Sakaguchi RL, Pintado MR. The wear of dental porcelain in an artificial mouth. Dent Mater 1986;2:214-219.

23. Al-Wahadni A. An in vitro investigation into the surface roughness of 2 glazed, unglazed, and refinished ceramic materials. Quintessence Int 2006;37:311-317.

24. Kwon SJ, Lawson NC, McLaren EE, Nejat AH, Burgess JO. Comparison of the mechanical properties of translucent zirconia and lithium disilicate. J Prosthet Dent 2018;120:132-137.

25. Green JI. Prevention and management of tooth wear: the role of dental technology. Prim Dent J 2016;5:30-33.

26. Purushotham S, Manjunath N, D'Souza ML, Shetty R. An interdisciplinar approach for the management of noncarious lesions. J Indian Soc Periodontol 2016;20:211-215. 